\title{
The role of post-adoption phase trust in B2C e-service loyalty: towards a more comprehensive picture
}

\author{
Matti Mäntymäki \\ Turku Centre for Computer Science (TUCS) \\ Turku School of Economics, Information Systems Science \\ Joukahaisenkatu 3-5 B, 6th floor \\ 20520 Turku \\ Finland \\ matti.mantymaki@tse.fi
}

\begin{abstract}
Despite the extensive interest in trust within information systems (IS) and e-commerce disciplines, only few studies examine trust in the postadoption phase of the customer relationship. Not only gaining new customers by increasing adoption, but also keeping the existing ones loyal, is largely considered important for e-business success. This paper scrutinizes the role of trust in customer loyalty, focusing on B2C e-services by conducting a threesectional literature review stemming from IS, e-commerce and marketing. The key findings of this study are: 1 . Literature discussing the role of trust after the adoption phase is relatively scarce and fragmented 2 . In the empirical testing trust is mostly viewed as a monolith 3 . Quantitative research methods dominate the field 4 . Since trust may play a role during the whole relationship, also dynamic ways to scrutinize trust would be appropriate. Implications of these findings are discussed and ideas for further research suggested.
\end{abstract}

\section{Introduction}

Trust has been viewed as one important factor affecting e-commerce adoption within the information systems (IS) and e-commerce disciplines $[1,2,3]$. The nature of trust has been widely discussed and its importance acknowledged also in e.g. e-commerce and marketing research streams [4]. Traditionally IS has been interested in adoption 
of technologies, such as Internet or e-commerce. However, from a customer relationship perspective the adoption represents only the first steps. The role of trust in post-adoption phase business-to-consumer (B2C) relationships has not been extensively discussed within the IS and e-commerce disciplines. Therefore, one can ask to what extent adoption alone is enough to explain customer relationships in the e-environment? One can also ponder whether consumers automatically continue usage after the adoption of the service and whether the same factors influencing adoption behavior play a role in the post-adoption phase? [5]

The importance of customer loyalty has been widely acknowledged and discussed in the marketing literature (see e.g. [6-9]). Customer loyalty is viewed as one of the most important factors for e-business' success [see. e.g. 10,11].

In this study, the customer means an individual consumer, not a corporate customer. With respect to loyalty, the term customer loyalty instead of consumer loyalty or service loyalty is used. Examples of the usage of the term customer loyalty in similar contexts can be found from the e-commerce body of research (cf. e.g. [26, $28,39])$.

In this study, B2C e-services are viewed in a rather wide sense as services that are delivered by commercial organizations to consumers via the Internet. Hence, services that are delivered using other electronic channels than the Internet are excluded from this study.

An increasing share of services is delivered using virtual channels. Hence, the service encounters are moving away from face-to-face interaction towards virtual encounters. Since service encounters are important for the relationship, organizations need to consider how to maintain and develop their customer relationships without the face-to-face component. As a result, understanding the post-adoption behavior requires further scrutiny. The contribution of the paper is three-fold; firstly, it investigates the role of trust in post-adoption phase of $\mathrm{B} 2 \mathrm{C}$ relationships in the online environment. Secondly, the paper scrutinizes the academic discussion around trust to identify topical areas of research and provides some longitudinal perspective on the development of the research. Thirdly, it attempts to identify possible paths for further research around trust and e-commerce.

\section{Research Approach}

The main focus of this paper is to discuss the role of trust in customer relationships of business-to-consumer (B2C) e-services, particularly in customer loyalty. As pointed out by Pavlou and Fygenson [12], consumer behavior has understandably largely ignored IT issues, since they have not been relevant in traditional physical business environment. Thus, this paper is positioned to contribute in narrowing the gap between IS and consumer behavior research as regards the role of trust.

A three-sectional literature review was conducted for this study. Figure 1 illustrates the areas and focus of the review. The first section focused on literature on trust in the Internet environment. To ascertain that the quality of the reviewed literature is sufficient, the top ten IS journals based on the Association for Information Systems Journal Rankings were included to the review. Because the idea 
is to investigate trust in online environment, articles published prior 1995 were excluded since the commercial usage of the Internet was rather limited before 1995 .

The second part of the review concentrated on e-commerce and e-services literature to find and investigate the studies discussing the role of trust in postadoption behavior, particularly in customer loyalty. The third section of the literature review focused on studies around trust and loyalty in consumer behavior literature within the marketing discipline.

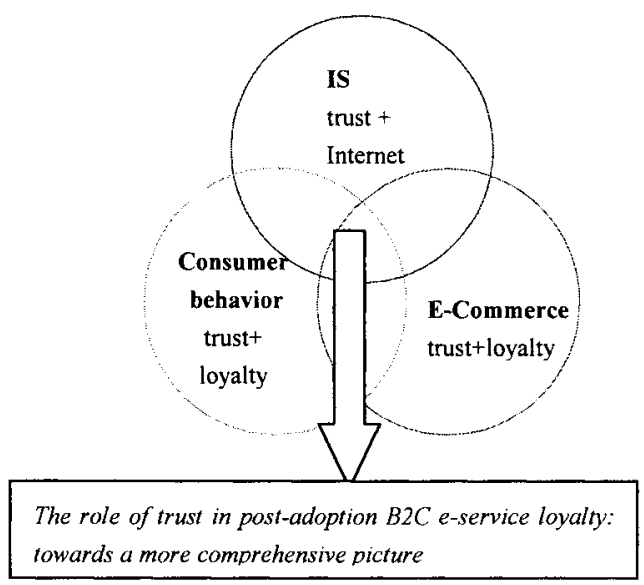

Figure 1. The structure of the study

\section{Background}

Trust has been in the interest of several disciplines. Trust has a central role in human interactions and hence in the society and economic exchange. The construct of trust can be approached from several directions using various theoretical frameworks. (cf. e.g. $[1,2,3]$.)

In the IS literature trust has been discussed in relation to e.g. e-commerce adoption [13], electronic marketplaces [14] and virtual teams [15]. In their studies, McKnight and Chervany [16] and McKnight et al. [2] have strived for bringing the dispositional, institutional and interpersonal aspects of trust into a single framework.

The e-commerce literature has generally focused more on the institutional $[17,18]$ than dispositional aspect of trust, yet the importance of dispositional trust in ecommerce is also acknowledged [13]. From a managerial perspective, influencing dispositional trust may be challenging since it stems from values and personality whereas institutional trust is built on structures such as laws, regulations, standards etc. that reduce the perceived risk. As a result, creating trust-building mechanisms to nurture trust is often faster and technically easier than trying to influence the psychological dimension of trust. 
Most of the online trust-building techniques are based on institution-based trust. Intuitively, institution-based trust seems effective also with B2C e-services. Structural assurances such as escrow services [17], privacy statements $[19,20]$ and feedback mechanisms [21, 14] are examples of commonly used trust-building techniques in e-commerce. In the case of e-services, the delivery of the service is automated. This reduces the risk of human errors and 'bad' service from the supplier side. On the other hand, the role of the customer in the e-service delivery is amplified. Therefore, achieving a high level of situational normality requires a technical environment where the customer is able to deliver the service without errors.

The view of trust in the literature has also somewhat evolved within the scrutinized period. In the early days, the focus was perhaps more on the security aspects to reduce the risk of fraud or misuse of personal data. The fundamental issue has shifted from convincing people that conducting transactions in the Internet is generally safe, towards lubricating the exchange and minimizing potential causes of inconvenience.

A topical trend is the critical evaluation of trust-building mechanisms [21, 22]. Issues related to feedback rating manipulations in electronic marketplaces and lack of customer attention and awareness of $3^{\text {rd }}$ party assurance seals and privacy policy statements $[23,20]$ may indicate that trust aspects will remain in the agenda. Increasing customer awareness of the reliability issues of feedback ratings in electronic marketplaces may underscore the significance of appropriate and transparent trust-building measures in the future.

Another topical issue is related to the cultural issues of trust in e-commerce. Traditionally, a vast majority of studies on trust in e-commerce have used populations of US students in the empirical research. Some recent studies have investigated the cultural differences concluding that cultural aspects are an issue that influences trust in e-commerce. $[24,25$.]

\section{Trust and B2C e-service relationships}

IS and e-commerce have discussed trust rather extensively but trust after the adoption phase has this far drawn less attention in these disciplines. Yet, signs of increasing interest towards post-adoption behaviors, e.g. customer loyalty have occurred in the recent IS and e-commerce literature [26, 27]. Table 1 illustrates the articles discussing trust and loyalty in the online $\mathrm{B} 2 \mathrm{C}$ context. The articles are found from databases EBSCOhost, Emerald, Elsevier, ProQuest/ABI Inform using search terms 'trust' AND 'loyalty'. Additional search terms, 'web', 'customer/consumer loyalty' and 'e-loyalty' were used to ensure that the most of relevant content is included in the search. From this group, articles focusing on online context and having trust as a variable or otherwise explicitly discussing trust were included. As can be seen from table 1, e-commerce/IS literature scrutinizing trust in $\mathrm{B} 2 \mathrm{C}$ eservices is sparse. Traditionally, customer loyalty has been discussed within consumer behavior in marketing and service loyalty within services marketing. 
146 The role of post-adoption phase trust in B2C e-service loyalty: towards a more comprehensive picture

Table 1. Articles on trust and customer loyalty

\begin{tabular}{|c|c|c|c|c|}
\hline Article & Area & $\begin{array}{l}\text { Theoretical } \\
\text { framework \& } \\
\text { Methods }\end{array}$ & View of trust & Key Ideas \\
\hline $\begin{array}{l}\text { Luarn \& } \\
\text { Lin }(2003) \\
{[28]}\end{array}$ & E-Service & $\begin{array}{l}\text { Quantitative } \\
\text { Trust- } \\
\text { commitment } \\
\text { theory } \\
\text { (Morgan \& Hunt } \\
\text { 1994) } \\
\text { Proposed loyalty } \\
\text { model }\end{array}$ & $\begin{array}{l}\text { Set of specific } \\
\text { beliefs (integrity, } \\
\text { benevolence, } \\
\text { competence and } \\
\text { predictability) } \\
\text { Monolith }\end{array}$ & $\begin{array}{l}\text { Commitment as a } \\
\text { powerful mediator } \\
\text { between trust, } \\
\text { satisfaction, } \\
\text { perceived value and } \\
\text { loyalty } \\
\text { Correlation between } \\
\text { trust and } \\
\text { commitment weaker } \\
\text { that satisfaction or } \\
\text { perceived value } \\
\text { Conceptualization } \\
\text { of "traditional" } \\
\text { customer loyalty in } \\
\text { e-service context }\end{array}$ \\
\hline $\begin{array}{l}\text { Li et al. } \\
(2006 a)[5]\end{array}$ & $\begin{array}{l}\text { E-commerce } \\
\text { / web site }\end{array}$ & $\begin{array}{l}\text { Investment } \\
\text { model for } \\
\text { interpersonal } \\
\text { relationships \& } \\
\text { commitment- } \\
\text { trust theory } \\
\text { Quantitative }\end{array}$ & $\begin{array}{l}\text { Monolith, however } \\
\text { the authors discuss } \\
\text { that trust is not } \\
\text { undimensional } \\
\text { Trust and } \\
\text { commitment the } \\
\text { predictors for } \\
\text { stickiness intention }\end{array}$ & $\begin{array}{l}\text { Commitment is a } \\
\text { stronger predictor } \\
\text { for stickiness than } \\
\text { trust. The impact of } \\
\text { trust also mediated } \\
\text { by commitment }\end{array}$ \\
\hline $\begin{array}{l}\text { Flavián \& } \\
\text { Guinalíu } \\
\text { (2006) [29] }\end{array}$ & E-commerce & $\begin{array}{l}\text { Quantitative } \\
\text { Proposes a } \\
\text { model that } \\
\text { relates trust, } \\
\text { privacy and } \\
\text { security with } \\
\text { loyalty to a web } \\
\text { site }\end{array}$ & Monolith & $\begin{array}{l}\text { Direct correlation } \\
\text { between trust and } \\
\text { loyalty, not only } \\
\text { intention to buy but } \\
\text { also preference, cost } \\
\text { and frequency of } \\
\text { visits. } \\
\text { Perceived security } \\
\text { as an important } \\
\text { antecedent of trust }\end{array}$ \\
\hline $\begin{array}{l}\text { Harris \& } \\
\text { Goode } \\
(2004)[30]\end{array}$ & $\begin{array}{l}\text { E-commerce } \\
\text { \& E-service } \\
\text { (Books.com } \\
\& \\
\text { Flights.com) }\end{array}$ & $\begin{array}{l}\text { Applying } \\
\text { Oliver's (1997) } \\
\text { sequential } \\
\text { loyalty chain in } \\
\text { an online } \\
\text { context }\end{array}$ & Monolith & $\begin{array}{l}\text { Trust as a central } \\
\text { driver of loyalty, } \\
\text { direct correlation } \\
\text { notified } \\
\text { Oliver's loyalty } \\
\text { model is reliable } \\
\text { and valid in the } \\
\text { online context. } \\
\text { nature of online } \\
\text { exchange rather } \\
\text { relational than } \\
\text { transactional }\end{array}$ \\
\hline
\end{tabular}




\begin{tabular}{|c|c|c|c|c|}
\hline $\begin{array}{l}\text { Thatcher \& } \\
\text { George } \\
(2004)[31]\end{array}$ & E-commerce & $\begin{array}{l}\text { TRA } \\
\text { Quantitative }\end{array}$ & $\begin{array}{l}\text { Trust in the } \\
\text { Internet } \\
\text { Monolith } \\
\text { Trust in the Internet } \\
\text { not correlated to } \\
\text { loyalty, once } \\
\text { consumers gain a } \\
\text { sufficient level of } \\
\text { experience to form } \\
\text { a committed } \\
\text { relationship to a } \\
\text { vendor } \rightarrow>\text { threshold } \\
\text { level? }\end{array}$ & $\begin{array}{l}\text { Existing marketing } \\
\text { models relevant are } \\
\text { for Web shopper } \\
\text { behavior. } \\
\text { Social involvement } \\
\text { magnifies the } \\
\text { relation between } \\
\text { commitment and } \\
\text { loyalty to a vendor. }\end{array}$ \\
\hline $\begin{array}{l}\text { Flavián et } \\
\text { al. (2006) } \\
{[32]}\end{array}$ & $\begin{array}{l}\text { Website } \\
\text { loyalty }\end{array}$ & $\begin{array}{l}\text { Quantitative } \\
\text { Explore the } \\
\text { influence of } \\
\text { perceived } \\
\text { website usability } \\
\text { on trust and } \\
\text { satisfaction and } \\
\text { the incidence of } \\
\text { these } 3 \text { variables } \\
\text { on loyalty }\end{array}$ & $\begin{array}{l}\text { Trust as set of } \\
\text { beliefs } \\
\text { Monolith }\end{array}$ & $\begin{array}{l}\text { The effect of } \\
\text { usability on loyalty } \\
\text { seems to be } \\
\text { conditioned by trust } \\
\text { and satisfaction }\end{array}$ \\
\hline $\begin{array}{l}\text { Li et al. } \\
(2006 b) \\
{[33]}\end{array}$ & $\begin{array}{l}\text { E- } \\
\text { Commerce } \\
\text { site }\end{array}$ & $\begin{array}{l}\text { The investment } \\
\text { model } \\
\text { Organizational } \\
\text { commitment } \\
\text { theory } \\
\text { Commitment- } \\
\text { trust theory } \\
\text { Quantitative }\end{array}$ & $\begin{array}{l}\text { Monolith } \\
\text { (focus on } \\
\text { commitment) }\end{array}$ & $\begin{array}{l}\text { Trust has a direct } \\
\text { impact on } \\
\text { behavioral intention } \\
\text { (return to the site) } \\
\text { and indirect via } \\
\text { affective } \\
\text { commitment } \\
\text { Trust between web } \\
\text { site and customer } \\
\text { increases likelihood } \\
\text { for use intentions. }\end{array}$ \\
\hline $\begin{array}{l}\text { Gummerus } \\
\text { et al. (2004) } \\
{[34]}\end{array}$ & $\begin{array}{l}\text { Services } \\
\text { Marketing } \\
\text { Online } \\
\text { health-care } \\
\text { service }\end{array}$ & $\begin{array}{l}\text { SERVQUAL } \\
\text { Satisfaction- } \\
\text { loyalty link } \\
\text { Quantitative }\end{array}$ & $\begin{array}{l}\text { Monolith } \\
\text { Trust as a mediator } \\
\text { between service } \\
\text { quality dimensions } \\
\text { and customer } \\
\text { satisfaction }\end{array}$ & $\begin{array}{l}\text { Service quality- } \\
\text { trust-satisfaction- } \\
\text { loyalty chain } \\
\text { Trust as an } \\
\text { important mediator } \\
\text { of customer loyalty }\end{array}$ \\
\hline $\begin{array}{l}\text { Cyr et al. } \\
(2007)[35]\end{array}$ & E-Service & $\begin{array}{l}\text { TAM (applied) } \\
\text { Quantitative }\end{array}$ & $\begin{array}{l}\text { Monolith, yet the } \\
\text { multidimensional } \\
\text { nature of trust is } \\
\text { discussed }\end{array}$ & $\begin{array}{l}\text { Trust mediates } \\
\text { between perceived } \\
\text { social presence and } \\
\text { e-loyalty }\end{array}$ \\
\hline $\begin{array}{l}\text { Anderson } \\
\& \\
\text { Srinivasan } \\
(2003)[10]\end{array}$ & E-commerce & $\begin{array}{l}\text { Loyalty \& } \\
\text { Satisfaction } \\
\text { Quantitative }\end{array}$ & Monolith & $\begin{array}{l}\text { Trust mediates } \\
\text { between E- } \\
\text { satisfaction and e- } \\
\text { loyalty }\end{array}$ \\
\hline $\begin{array}{l}\text { Ribbink et } \\
\text { al. (2004) } \\
{[36]}\end{array}$ & $\begin{array}{l}\text { Services } \\
\text { Marketing }\end{array}$ & $\begin{array}{l}\text { Loyalty } \\
\text { literature } \\
\text { Quantitative } \\
\end{array}$ & $\begin{array}{l}\text { Trust viewed only } \\
\text { as trust to an e- } \\
\text { tailer, yet other }\end{array}$ & $\begin{array}{l}\text { E-trust has a } \\
\text { moderate direct } \\
\text { impact on e-loyal }\end{array}$ \\
\hline
\end{tabular}




\begin{tabular}{|c|c|c|c|c|}
\hline & & & $\begin{array}{l}\text { aspects i.e. } \\
\text { dispositional, } \\
\text { system-based and } \\
\text { interpersonal are } \\
\text { discussed. }\end{array}$ & $\begin{array}{l}\text { but weaker than e- } \\
\text { satisfaction has. E- } \\
\text { trust also mediates } \\
\text { between e- } \\
\text { satisfaction and e- } \\
\text { loyalty }\end{array}$ \\
\hline $\begin{array}{l}\text { Pitta et al. } \\
(2006)[37]\end{array}$ & Marketing & $\begin{array}{l}\text { Conceptual } \\
\text { paper } \\
\text { Marketing } \\
\text { literature }\end{array}$ & Multi-dimensional & $\begin{array}{l}\text { Trust needs to be } \\
\text { nurtured throughout } \\
\text { the whole customer } \\
\text { relationship to keep } \\
\text { customer loyal }\end{array}$ \\
\hline $\begin{array}{l}\mathrm{Ha} \mathrm{(2004)} \\
{[38]}\end{array}$ & Marketing & $\begin{array}{l}\text { Quantitative } \\
\text { web survey } \\
\text { Marketing } \\
\text { literature }\end{array}$ & $\begin{array}{l}\text { Brand trust } \\
\text { Monolith }\end{array}$ & $\begin{array}{l}\text { Brand trust an } \\
\text { important factor for } \\
\text { relationship length } \\
\text { Community } \\
\text { keystone for brand } \\
\text { trust } \\
\text { Brand trust affects } \\
\text { commitment }\end{array}$ \\
\hline $\begin{array}{l}\text { Gefen et al. } \\
(2003) \text { [13] }\end{array}$ & $\begin{array}{l}\text { Online } \\
\text { shopping }\end{array}$ & $\begin{array}{l}\text { TAM } \\
\text { Quantitative }\end{array}$ & Multi-dimensional & $\begin{array}{l}\text { Trust in repeat } \\
\text { purchasing }\end{array}$ \\
\hline $\begin{array}{l}\text { Floh \& } \\
\text { Treiblmaier } \\
(2006) \text { [39] }\end{array}$ & $\begin{array}{l}\text { Internet } \\
\text { Banking }\end{array}$ & $\begin{array}{l}\text { Multigroup } \\
\text { analysis } \\
\text { Quantitative }\end{array}$ & Monolith & $\begin{array}{l}\text { Trust mediates the } \\
\text { impact of service } \\
\text { quality and web site } \\
\text { quality on loyalty. }\end{array}$ \\
\hline
\end{tabular}

\section{Discussion}

\subsection{Implications for research}

Literature discussing trust after the e-service adoption and its influence on customer loyalty is scarce and fragmented across marketing and e-commerce. In the studies investigating the role of trust with other relationship constructs such as satisfaction, perceived value or commitment, trust is largely viewed as a monolith. This approach leaves the multi-dimensional, complex nature of trust reported in numerous studies largely, ignored in the empirical testing.

Quantitative research methods are dominant within the area of trust and customer loyalty, yet the recent literature also contains a qualitative example [40]. Quantitative methods enable measuring correlations between the key constructs. In the light of previous studies, trust seems to correlate with numerous relationship components. In addition, quantitative methods are only able to provide a static picture leaving the dynamics of trust, also acknowledged by scholars, without further scrutiny.

Due to varying setting of hypotheses in different studies it is problematic to interpret how trust in positioned among the other related constructs such as perceived value, service quality, satisfaction and loyalty. This either underscores the complex, 
multi-faceted nature of trust, or reflects that capturing 'the true nature' of trust can be challenging.

For this paper the literature review discussing trust and customer loyalty was not conducted systematically but using search terms. This can be viewed as a limitation for the study since it is possible only with a systematic review to ensure that the relevant articles are included. However, if the literature discussing the topic is fragmented across several disciplines and journals, as it is in this case, conducting a systematic, holistic literature review can be somewhat challenging.

\subsection{Implications for business}

Trust appears to be a central component of customer relationship during the whole customer lifecycle, not only a factor affecting the adoption. However, the relationship between trust and other relationship components may require further clarification. A 'trust threshold' that businesses need to exceed to convince customers may not be static, but shifts over time. As a result, trust management is an ongoing process.

\subsection{Future research}

Widening the view of trust from monolith to multi-dimensional would draw a more comprehensive picture of trust in the post-adoption phase. Extending the array of methodological choices from strictly quantitative analysis to other methods, such as case study approach or ethnographical research, could potentially enrich the picture of trust in the post-adoption phase. It could also include a longitudinal perspective to better grasp the dynamic nature of trust.

\section{Conclusions}

This paper has scrutinized the role of trust in post-adoption phase of $\mathrm{B} 2 \mathrm{C}$ e-services. Based on the findings of this study, trust seems to be an important, yet multi-faceted factor after adoption, since it correlates with several relationship elements such as commitment and loyalty. Therefore, the development and increasing adoption of ecommerce and e-services have not reduced the importance of trust in understanding online consumer behavior. In this light, further research on post-adoption trust seems appropriate.

\section{Acknowledgements}

The author gratefully acknowledges the financial support received from Jenny and Antti Wihuri Foundation, Foundation for Economic Education and Turun Kauppaopetussäätiö (Foundation for Economic Education in Turku). 
150 The role of post-adoption phase trust in B2C e-service loyalty: towards a more comprehensive picture

\section{References}

1. M.O.K Lee and E Turban, A Trust Model for Consumer Internet Shopping, International Journal of Electronic Commerce 6(1), 75-91 (2001)

2. H.D McKnight, V. Choudhury, and C. Kacmar, Developing and Validating Trust Measures for e-Commerce: An Integrative Typology Informations Systems Research 13(3), 334-359 (2002).

3. S. Grabner-Kräuter and E.A. Kaluscha, Empirical research in on-line trust: a review and critical assessment, International Journal of Human-Computer Studies 58(6), 783-812 (2003).

4. A.E. Schlosser, T.B. White, and S.M. Lloyd, Converting Web Site Visitors into Buyers: How Web Site Investment Increases Consumer Trusting Beliefs and Online Purchase Intentions, Journal of Marketing 70(April 2006), 133-148 (2006).

5. D. Li, G.J. Browne, and P.Y.K Chau, An Empirical Investigation of Web Site Use Using a Commitment-Based Model", Decision Sciences 37(3), 427-443 (2006).

6. R.L. Oliver, Satisfaction: a behavioral perspective on the consumer (McGraw-Hill, New York, 1997).

7. R.L.Oliver, Whence Consumer Loyalty?, Journal of Marketing, 63(October 1999 Special Issue), 33-44 (1999).

8. M.T. Copeland, "Relation of consumers' buying habits to marketing methods", Harvard Business Review 1(3), 282-289 (1923).

9. J. Jacoby and R.W. Chestnut, Brand Loyalty Measurement and Management (John Wiley \& Sons, New York, 1978).

10. R.E. Anderson and S.S. Srinivasan, E-satisfaction and e-loyalty: a contingency framework, Psychology and Marketing 20(2), 123-138 (2003).

11. F.F. Reicheld and P. Schefter, E-loyalty - Your Secret Weapon on the Web, Harvard Business Review 78(7-8), 105-113 (2000).

12. P.A. Pavlou and M. Fygenson, Understanding and Predicting Electronic Commerce Adoption: An Extension of the Theory of Planned Behaviour, MIS Quarterly 30(1), 115-143 (2006).

13. D. Gefen, E. Karahanna, and D.W. Straub, Trust and TAM in Online Shopping, An Integrated Model, MIS Quarterly 27(1), 51-90 (2003).

14. S. Ba and P.A. Pavlou, Evidence of the Effect of Trust Building Technology in Electronic Markets: Price Premiums and Buyer Behavior, MIS Quarterly 26(3), 243-268 (2002).

15. S.L. Järvenpää, T.R. Shaw, and S.D. Staples, Toward Contextualized Theories of Trust: The Role of Trust is Global Virtual Teams, Information Systems Research 15(3), 250267 (2004)

16. D.H. McKnight and N.L. Chervany, What Trust Means in E-Commerce Customer Relationships: An Interdisciplinary Conceptual Typology, International Journal of Electronic Commerce 6(2) 35-59 (2002).

17 X. Hu, Z. Lin, A.B. Whinston, and H. Zhang, Hope or Hype: On the Viability of Escrow Services as Trusted Third Parties in Online Auction Environments, Information Systems Research 15(3), 236-249 (2004).

18. P. Ratnasingam, D. Gefen and P. A. Pavlou, The Role of Facilitating Conditions and Institutional Trust in Electronic Marketplaces, Journal of Electronic Commerce in Organizations 3(3), 69-82 (2005). 
19. I. Pollach, Privacy Statements as a Means of Uncertainty Reduction in WWW Auctions, Journal of Organizational and End User Computing 18(1), 23-49 (2006).

20. D.B. Meinert, D.K. Peterson, J.R. Criswell, and M.D. Crossland, Privacy Policy Statements and Consumer Willingness to Provide Personal Information, Journal of Electronic Commerce in Organizations 4(1), 1-17 (2006).

21. A. Josang, R. Ismail, and C. Boyd, A survey of trust and reputation systems for online service provision, Decision Support Systems 43(2), 618-644 (2007).

22. J. Brown and J. Morgan, Reputation in Online Auctions: The Market For Trust, California Management Review 49(1), 61-81 (2006).

23. K.M. Kimery and M. McCord, Signals of Trustworthiness in E-Commerce: Consumer Understanding of Third-Party Assurance Seals, Journal of Electronic Commerce in Organizations 4(4) 52-74 (2006).

24. D. Gefen and T. Heart, On the Need to Include National Culture as a Central Issue in E-Commerce Trust Beliefs, Journal of Global Information Technology Management 14(4), 130 (2006).

25. T.S.H Teo, and J. Liu, Consumer trust in e-commerce in the United States, Singapore and China, Omega - The International Journal of Management Science 35(1), 22-38 (2007).

26. S. Otim and V. Grover, An empirical study on Web-based services and customer loyalty, European Journal of Information Systems 15(6), 527-541 (2006).

27. F. Wang and M. Head, How can the Web help build customer relationships? An empirical study on e-tailing, Information \& Management 44(2), 115-129 (2007).

28. P. Luarn and H-H. Lin, A Customer Loyalty Model for E-Service Context, Journal of Electronic Commerce Research 4(4), 156-167 (2003).

29. C. Flavián and M. Guinalíu, Consumer trust, perceived security and privacy policy Three basic elements of loyalty to a web site, Industrial Management \& Data Systems 106(5) 601-620 (2006)

30. L.C. Harris and M.H. Goode, The four levels of loyalty and the pivotal role of trust: a study of online service dynamics, Journal of Retailing 15(6), 139-158 (2004).

31. J.B. Thatcher and J.F. George, Commitment, Trust and Social Involvement: An Exploratory Study of Antecedents to Web Shopper Loyalty, Journal of Organizational Computing and Electronic Commerce 14(4), 243-268 (2004)

32. C. Flavián, M. Guinalíu, and Raquel Gurrea, The role played by perceived usability, satisfaction and trust on website loyalty, Information and Management 4(1), 1-14 (2006).

33. D. Li, G.J. Browne, and J.C. Wetherbe, Why Do Internet Users Stick with a Specific Web Site? A Relationship Perspective, International Journal of Electronic Commerce 10(4), 105-141 (2006).

34. J. Gummerus, V. Liljander, M. Pura, M. and A. van Riel, Customer loyalty to contentbased web sites: the case of an online health-care service, Journal of Services Marketing 18(3) 175-186 (2004).

35. D. Cyr, K. Hassanein, M. Head, and A. Ivanov, The role of social presence in establishing loyalty in e-Service environments, Interacting with Computers 19(1)43-56 (2007).

36. D. Ribbink, A.C.R. van Riel, V. Liljander, and S. Streukens, Comfort your online customer: quality trust and loyalty on the internet, Managing Service Quality 14(6), 446-456 (2004)

37. D.A. Pitta and D. Fowler, Internet community forums: an untapped resource for consumer marketers, Journal of Consumer Marketing 22(5), 265-2.74 (2005) 
152 The role of post-adoption phase trust in B2C e-service loyalty: towards a more comprehensive picture

38. H-Y. Ha, Factors Affecting Online Relationships and Impacts, The Marketing Review 4(2), 189-209 (2004).

39. A. Floh. and H. Treiblmaier, What Keeps the E-Banking Customer Loyal? A Multigroup Analysis of the Moderating Role of Consumer Characteristics on E-Loyalty in th Financial Service Industry, Journal of Electronic Commerce Research 7(2), 97-110 (2006).

40. K. Pennanen, T. Tiainen, and H.T. Luomala, A qualitative exploration of a consumer's value based trust: A framework development, Qualitative Market Research: An International Journal 10(1), 28-57 (2007). 